\begin{tabular}{|c|l|}
\hline Title & Carrier-microencapsulation for preventing pyrite oxidation \\
\hline Author(s) & Satur, Jacqueline; Hiroyoshi, Naoki; Tsunekawa, Masami; Ito, May umi; Okamoto, Hidey uki \\
\hline Citation & $\begin{array}{l}\text { International Journal of Mineral Processing, 83(3-4), 116-124 } \\
\text { https://loi.org/10.1016/.minpro.2007.06.003 }\end{array}$ \\
\hline Issue Date & $2007-09-21$ \\
\hline Doc URL & http://hdl.handle.net/2115/30238 \\
\hline Type & article (author version) \\
\hline File Information & IJMP83-34.pdf \\
\hline
\end{tabular}

Instructions for use 


\title{
Carrier-Microencapsulation for Preventing Pyrite Oxidation
}

\author{
Jacqueline Satur ${ }^{\text {a, }}$, Naoki Hiroyoshi ${ }^{\text {a }}$, Masami Tsunekawa ${ }^{\text {a }}$, Mayumi Ito ${ }^{\text {a }}$, Hideyuki \\ Okamoto $^{\mathrm{b}}$ \\ ${ }^{a}$ Graduate School of Engineering, Hokkaido University, Kita 13, Nishi 8, Kita-ku, Sapporo \\ 060-8628, Hokkaido, Japan \\ ${ }^{b}$ Sumitomo Metal Mining Company, Japan
}

\begin{abstract}
The oxidation of pyrite causes the formation of acid mine drainage polluted by heavy metals. This paper proposes carrier-microencapsulation (CME) for preventing pyrite oxidation. In CME, an organic agent is used as an in-situ carrier for transporting Ti from $\mathrm{Ti}$ minerals to the pyrite surface through an aqueous phase. Then, the organic carrier is decomposed and $\mathrm{Ti}(\mathrm{OH})_{4}$ or $\mathrm{TiO}_{2}$ film is formed on the pyrite surface as a protective coating against oxidation.

To demonstrate the effect of CME on pyrite oxidation, shaking-flask leaching experiments of ground pyrite were performed at $298 \mathrm{~K}$ in air for 25 days, with or without anatase $\left(\mathrm{TiO}_{2}\right)$ and catechol (1,2-dihydroxybenzene) as the organic carrier. The amounts of $\mathrm{Fe}$ and $\mathrm{S}$ extracted from the pyrite were lower with $\mathrm{TiO}_{2}$ and catechol than without $\mathrm{TiO}_{2}$ or catechol, indicating that CME using $\mathrm{TiO}_{2}$ and catechol is effective in suppressing pyrite oxidation. When $\mathrm{TiO}_{2}$ and catechol coexist, the $\mathrm{Ti}$ concentration in the solution phase increased initially and then decreased. SEM-EDX analysis of the CME-treated pyrite showed that $\mathrm{Ti}$ and $\mathrm{O}$ are present on the pyrite surface. Cyclic voltammogram of catechol showed that catechol was oxidized on pyrite electrode. These results indicate that $\mathrm{Ti}$ is extracted from $\mathrm{TiO}_{2}$ by catechol as a Ti-catechol complex and that the complex is adsorbed and oxidized on pyrite to form a $\mathrm{Ti}(\mathrm{OH})_{4}$ or $\mathrm{TiO}_{2}$ coating suppressing pyrite oxidation.
\end{abstract}

Keywords: Pyrite; Tailings disposal; Leaching; Acid mine drainage; Microencapsulation

* Corresponding author. Telefax: 81-0117066315

E-mail address: jackie@eng.hokudai.ac.jp (Jacqueline Satur) 


\section{Introduction}

Pyrite, $\mathrm{FeS}_{2}$, is a common sulfide mineral present very widely in the earth's crust. Pyrite is stable under anaerobic conditions but is oxidized and dissolved to release soluble iron species and sulfuric acid when it comes in contact with oxygen and water. The sulfuric acid lowers the $\mathrm{pH}$ of the waters and enhances metal extraction from coexisting minerals. Thus pyrite dissolution causes the formation of acidic waters polluted by various metal ions, e.g. lead and arsenic, and brings about serious environmental problems. This phenomenon is called as Acid Rock Drainage or ARD. It is frequently discharged from mining sites (then referred to as Acid Mine Drainage or AMD) and underground excavation sites for subway and tunnel construction (Nagasawa et al., 2004), and also occurs naturally.

To prevent ARD formation, many methods have been proposed for suppressing pyrite oxidation and one of the promising methods is microencapsulation. In this method, a thin protective coating is formed on pyrite surface which inhibits oxygen diffusion to pyrite surface (Evangelou, 1995). It was reported that the microencapsulation using phosphate and silicate coatings was effective for preventing pyrite oxidation in column leaching experiments that lasted 1.25 years (Evangelou, 2001). The protective coatings were formed using a solution composed of hydrogen peroxide or hypochlorite as preoxidant, $\mathrm{KH}_{2} \mathrm{PO}_{4}$ or $\mathrm{H}_{4} \mathrm{SiO}_{4}$, and sodium acetate or limestone as $\mathrm{pH}$ buffer.

Other materials have been employed to form a protective coating on pyrite against oxidation such as organic compounds containing hydroxyl functional groups (Chander and Zhou, 1992), natural phosphate rocks and bacterial growth media (Kalin et al., 1998), and lipids having two organic hydrophobic tails and a polar hydrophilic head group (Elsetinow et al., 2003).

In the present study, the authors propose carrier-microencapsulation (CME) as a new technique for making the protective coatings. Fig. 1 is a schematic representation of CME. In CME, an organic agent is used as a carrier for Ti $\left(9^{\text {th }}\right.$ most abundant element in the earth's crust, $0.57 \%$ by mass (Taylor, 1964)), transporting it from Ti minerals to the pyrite surface through the aqueous phase. Then, the organic carrier is decomposed and $\mathrm{TiO}_{2}$ or $\operatorname{Ti}(\mathrm{OH})_{4}$ film is formed on the pyrite surface as a protective coating against oxidation. Because $\mathrm{TiO}_{2}$ is very stable thermodynamically and resistant against chemical attacks by acids, alkalis, oxidant, and reductant, it may be expected that $\mathrm{CME}$ using $\mathrm{TiO}_{2}$ as a protective coating can prevent pyrite oxidation over a long time. To demonstrate the effect of CME on pyrite oxidation, $\mathrm{CME}$ was conducted using catechol (1,2-dihydroxybenzene) as an organic carrier for forming $\mathrm{TiO}_{2}$ or $\mathrm{Ti}(\mathrm{OH})_{4}$ coating on pyrite surface.

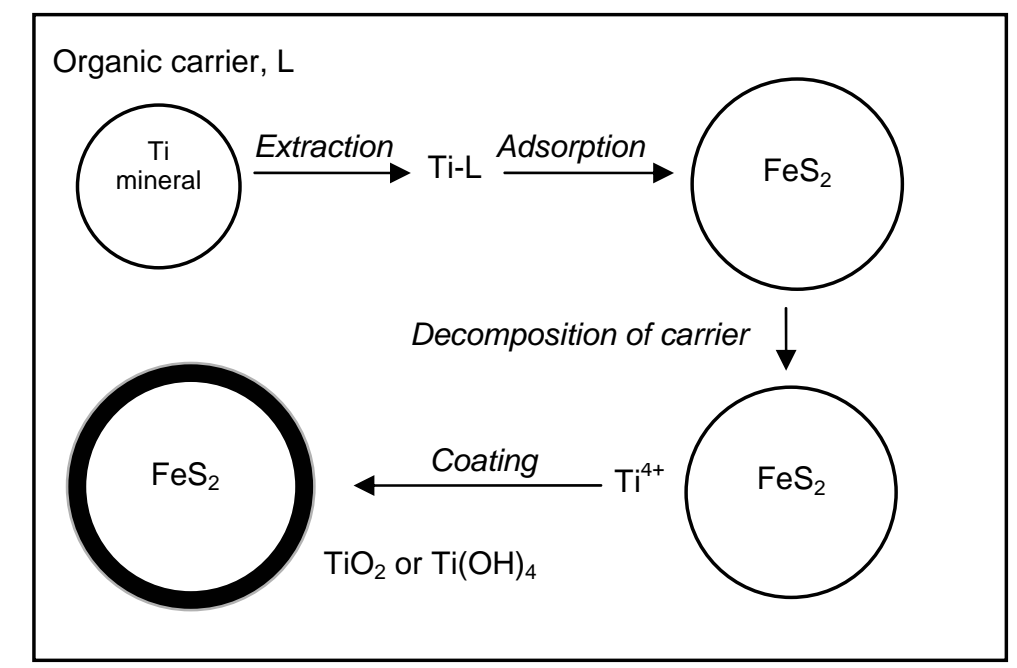

Fig. 1. Schematic illustration of carrier-microencapsulation (CME). 


\section{Materials and methods}

Raw pyrite was obtained from Yanahara Mine, Okayama, Japan. It was ground by a ball mill and then dry-sieved to obtain $+53-75 \mu \mathrm{m}$ fraction. To remove the oxidized surface layer and to obtain a stoichiometric surface of pyrite, the washing method done by Sasaki et al. (1995) was adapted. The sieved sample was washed with ethanol in a beaker placed inside an ultrasonic vibrator for $30 \mathrm{~s}$. Then, the ethanol was decanted and the pyrite was washed subsequently with $1 \mathrm{~N} \mathrm{HNO}_{3}$, distilled water (two times), and acetone (four times). Finally, the washed pyrite was vacuum-dried. Table 1 gives the chemical composition of the pyrite sample determined by SEIKO SPS7800 Inductively Coupled Plasma-Atomic Emission Spectrometer (ICP-AES) after acid digestion of $0.1 \mathrm{~g}$ of the sample in $5 \mathrm{~cm}^{3}$ of $60 \% \mathrm{HNO}_{3}, 1$ $\mathrm{cm}^{3}$ of $96 \% \mathrm{HClO}_{4}$, and $1 \mathrm{~cm}^{3}$ of $50 \% \mathrm{HF}$ inside a laboratory microwave. Assuming that the particle's shape is sphere, the specific surface area of the pyrite was calculated from its mean particle diameter $(64 \mu \mathrm{m})$ and density $\left(5.02 \mathrm{~g} \mathrm{~cm}^{-3}\right)$, and was equal to $18.7 \mathrm{~m}^{2} \mathrm{~kg}^{-1}$.

Reagent grade anatase and rutile $\mathrm{TiO}_{2}$ powder (Wako Chemical Co. Ltd.) were used instead of natural Ti minerals. Specific surface area of anatase and rutile determined by BET method using $\mathrm{N}_{2}$ were $17.6 \mathrm{~m}^{2} \mathrm{~g}^{-1}$ and $14.1 \mathrm{~m}^{2} \mathrm{~g}^{-1}$, respectively.

As an organic carrier, reagent grade catechol (1,2-dihydroxybenzene, $\mathrm{C}_{6} \mathrm{H}_{4}(\mathrm{OH})_{2}$, Wako Chemical Co. Ltd.) was used. Catechol solutions were prepared by dissolving known masses of catechol in ion exchange-distilled water and $\mathrm{pH}$ was adjusted whenever required by addition of $\mathrm{H}_{2} \mathrm{SO}_{4}$ or $\mathrm{NaOH}$.

Shaking-flask experiments were employed using a water bath shaker (shaking rate, 120 strokes $\mathrm{min}^{-1}$; temperature, $25^{\circ} \mathrm{C}$ ) to evaluate the ability of catechol to extract $\mathrm{Ti}$ from $\mathrm{TiO}_{2}$, the adsorption of $\mathrm{Ti}$ on pyrite from aqueous phase, and the effects of CME on pyrite oxidation, as detailed in the following sections. The solutions were collected by membrane filters (pore size, $0.2 \mu \mathrm{m}$ ) and $\mathrm{Ti}, \mathrm{Fe}$, and $\mathrm{S}$ concentrations in the filtrates were measured by ICP-AES. In a part of the experiments, the pyrite residue was collected by filtration and vacuum-dried overnight at $50^{\circ} \mathrm{C}$ for Scanning Electron Microscopy and Energy Dispersion $\mathrm{X}$-ray (SEM-EDX) analysis.

To investigate the oxidation of catechol on pyrite, cyclic voltammetry was carried out using pyrite working electrode, $\mathrm{Pt}$ counter electrode, and saturated $\mathrm{Ag}-\mathrm{AgCl}$ reference electrode in $10 \mathrm{~mol} \mathrm{~m}^{-3} \mathrm{Na}_{2} \mathrm{SO}_{4}$ solution with or without $10 \mathrm{~mol} \mathrm{~m}^{-3}$ catechol at $25^{\circ} \mathrm{C}$ and natural $\mathrm{pH}\left(\mathrm{pH}\right.$ 5-6) under $\mathrm{N}_{2}$ atmosphere. Potential scan was initiated from the rest potential of pyrite electrode to anodic direction using a scan rate of $0.005 \mathrm{~V} \mathrm{~s}^{-1}$.

\section{Results and discussion}

\subsection{Extraction of Ti from $\mathrm{TiO}_{2}$ by catechol}

To confirm the ability of catechol to extract $\mathrm{Ti}$ from $\mathrm{TiO}_{2}$, shaking-flask experiments were carried out for 1 day with a $50-\mathrm{cm}^{3}$ Erlenmeyer flask containing $1 \mathrm{~g}$ of $\mathrm{TiO}_{2}$ (anatase and rutile) and $10 \mathrm{~cm}^{3}$ of catechol solution.

Fig. 2 shows the amount of $\mathrm{Ti}$ extracted for 1 day as a function of catechol concentration at natural $\mathrm{pH}$ condition $(\mathrm{pH} 5-6)$. The amount increased with increasing catechol concentration, confirming that catechol acts as an extractant for Ti. The amount of Ti extracted from anatase was higher than from rutile. Maximum percentage of Ti extracted from anatase was $0.001 \%$ and from rutile was $0.0001 \%$ using $100 \mathrm{~mol} \mathrm{~m}{ }^{-3}$ catechol. 


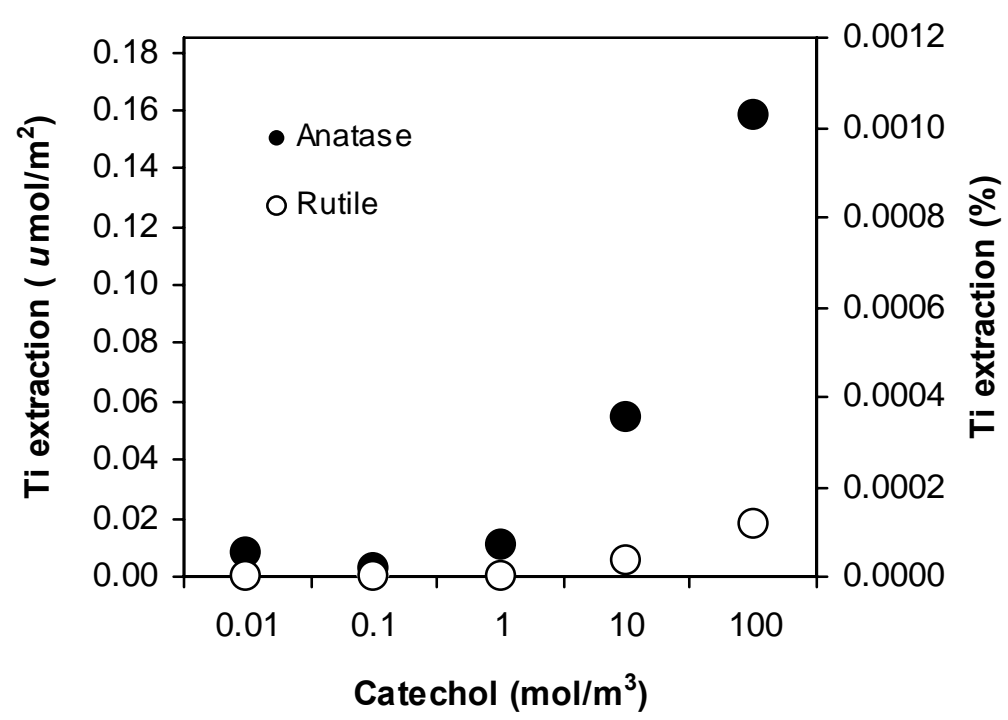

Fig. 2. Effect of catechol concentration on the amount of Ti extracted per unit surface area of $\mathrm{TiO}_{2}$ at natural $\mathrm{pH}(\mathrm{pH} 5-6)$ after 1 day.

Fig. 3 shows the effect of $\mathrm{pH}$ on Ti extraction from $\mathrm{TiO}_{2}$ in the presence of $100 \mathrm{~mol}$ $\mathrm{m}^{-3}$ catechol for 1 day. In the acidic region, the amount of Ti extracted was very low but it increased with increasing $\mathrm{pH}$ and significant amount of $\mathrm{Ti}$ was extracted from $\mathrm{TiO}_{2}$ at above $\mathrm{pH} 4$ for anatase and at above $\mathrm{pH} 6$ for rutile. Maximum percentage of Ti extracted from anatase was $0.03 \%$ and from rutile was $0.01 \%$ at about $\mathrm{pH} 8$.

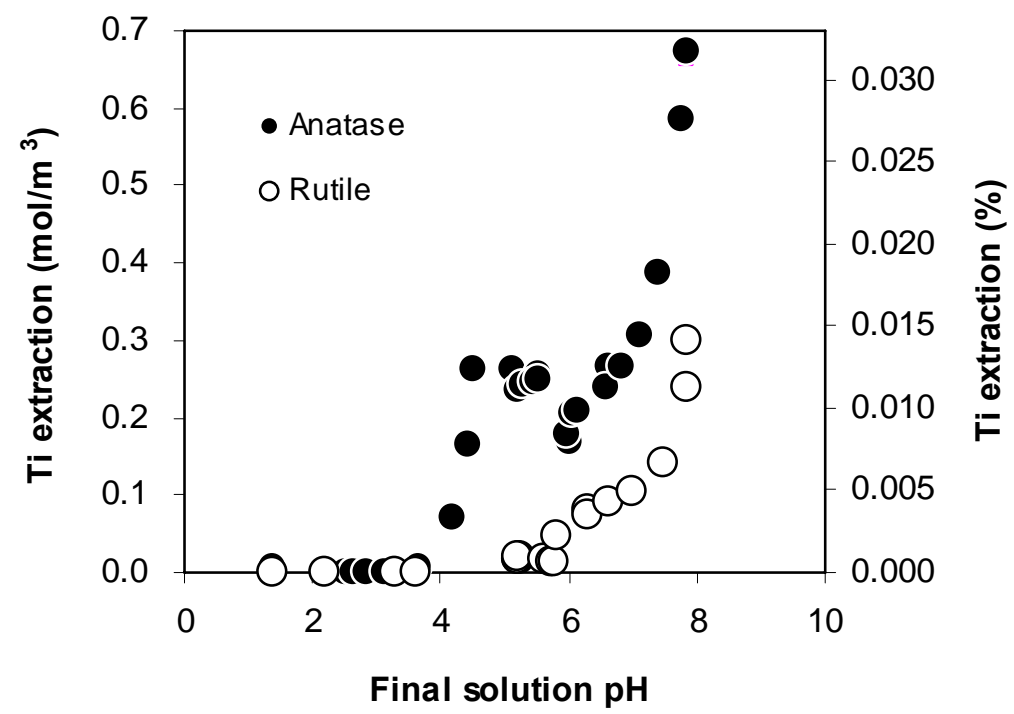

Fig. 3. Effect of $\mathrm{pH}$ on the amount of Ti extracted from $\mathrm{TiO}_{2}$ in the presence of $100 \mathrm{~mol} \mathrm{~m}^{-3}$ catechol after 1 day.

Catechol is a weak diprotic acid $\left(\mathrm{pKa}_{1}=9.2, \mathrm{pKa}_{2}=13.0\right)$ and is present in the undissociated form over a wide $\mathrm{pH}$ range (Rodriguez et al., 1996). It was also reported that catechol forms a tris complex with $\mathrm{Ti}, \mathrm{Ti}\left(\mathrm{C}_{6} \mathrm{H}_{4} \mathrm{O}_{2}\right)_{3}{ }_{3}^{2-}$, and this complex is stable from pH 612 (Raymond et al., 1984). The extraction of $\mathrm{Ti}$ from $\mathrm{TiO}_{2}$ by catechol is assumed to be due to the following reaction: 


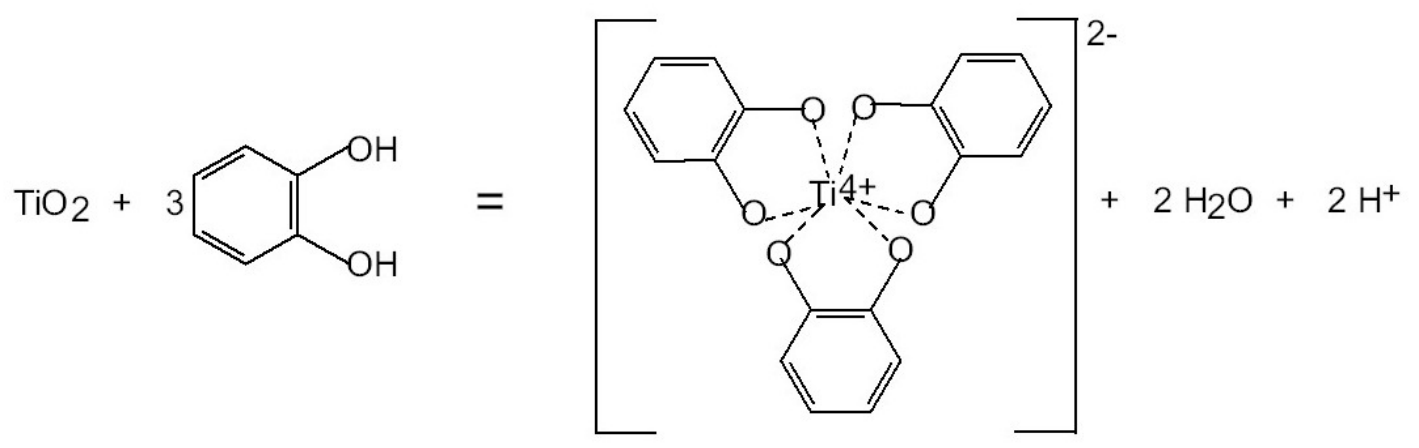

As in the above equation, protons $\left(\mathrm{H}^{+}\right)$are a product of the $\mathrm{TiO}_{2}$ dissolution. This may be the reason why $\mathrm{TiO}_{2}$ dissolution is suppressed at low $\mathrm{pH}$ where the $\mathrm{H}^{+}$concentrations are high. In support to this, $\mathrm{pH}$ decreased with time as $\mathrm{Ti}$ was extracted by catechol (separate experiment, data not shown). This agrees with Eq. 1.

\subsection{Adsorption of Ti on pyrite from Ti-catechol complex solutions}

The adsorption of Ti on pyrite from Ti-catechol complex solutions was next evaluated. Ti-catechol complex solutions of varying $\mathrm{Ti}$ concentrations but constant total catechol concentration of $100 \mathrm{~mol} \mathrm{~m}^{-3}$ were prepared by shaking-flask experiment of $1 \mathrm{~g}$ anatase $\mathrm{TiO}_{2}$ in $10 \mathrm{~cm}^{3}$ of $100 \mathrm{~mol} \mathrm{~m}^{-3}$ catechol solution (Section 3.1) and diluting the resulting Ticatechol complex solution with $100 \mathrm{~mol} \mathrm{~m}^{-3}$ catechol solution.

Fifty- $\mathrm{cm}^{3}$ Erlenmeyer flasks containing $10 \mathrm{~cm}^{3}$ of the diluted Ti-catechol complex solution and $6 \mathrm{~g}$ of pyrite were shaken at $25^{\circ} \mathrm{C}$ for 1 day in air or in $\mathrm{N}_{2}$ and Ti concentrations in the filtrates were determined. A preliminary experiment without pyrite confirmed that $\mathrm{Ti}$ does not precipitate from the solution phase. The adsorption amount of $\mathrm{Ti}$ on pyrite surface was calculated by subtracting the Ti concentration in the filtrate from the Ti concentration in the Ti-catechol complex solution. Following similar procedures, the adsorption of Ti ions on silica was also investigated.

Fig. 4 shows the amount of $\mathrm{Ti}$ adsorbed on $1 \mathrm{~g}$ of pyrite as a function of $\mathrm{Ti}$ concentration after 1 day shaking in air. The initial $\mathrm{pH}$ values of the prepared Ti-catechol complex solutions were from $\mathrm{pH}$ 4.5-5.0 and final $\mathrm{pH}$ values after mixing with pyrite were from $\mathrm{pH} 3.0-3.20$. The result indicates that $\mathrm{Ti}$ was adsorbed on pyrite from the solution containing the Ti-catechol complex and that adsorption amounts increased with increasing Ti concentration. A rough estimate of the thickness of the $\mathrm{TiO}_{2}$ coating on pyrite particle was obtained from the maximum amount of $\mathrm{Ti}$ adsorbed per unit surface area of pyrite and from the assumption that the coating is of anatase properties. The calculated thickness was 0.164 $\mathrm{nm}$. 


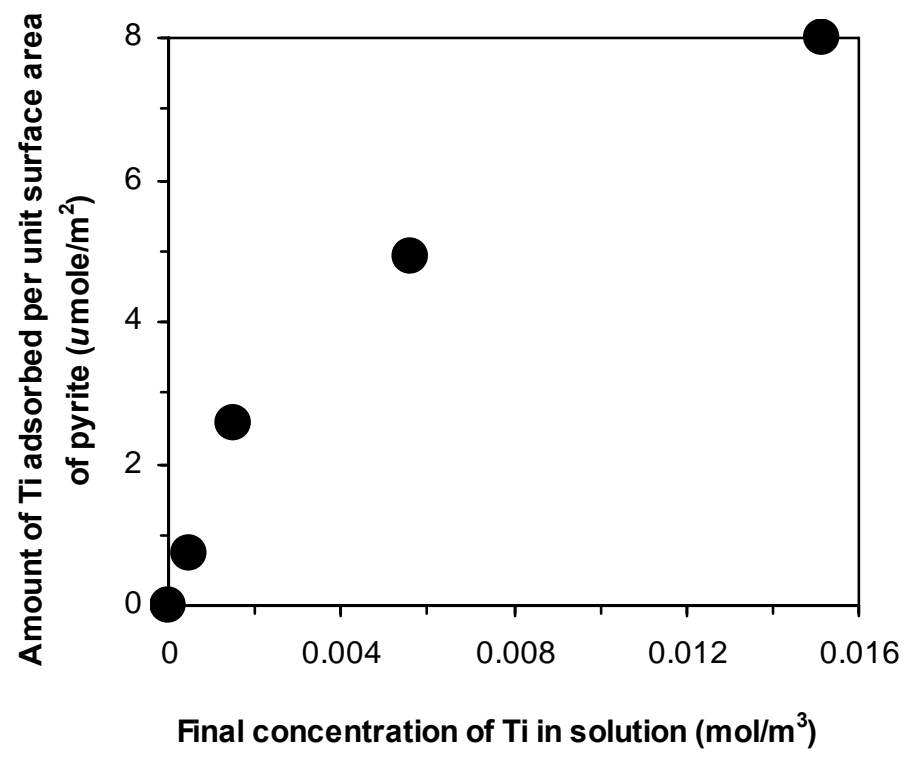

Fig. 4. Relationship between the amount of Ti adsorbed per unit surface area of pyrite and final concentration of $\mathrm{Ti}$ in solution after 1 day at $25^{\circ} \mathrm{C}$. Initial $\mathrm{pH}, 4.5-5.0$; final $\mathrm{pH}, 3.0-3.2$.

Fig. 5 shows the comparison of the amounts of Ti adsorbed on pyrite and on silica in the presence or absence of $\mathrm{O}_{2}$. Adsorption amount of Ti on silica was negligible and Ti was selectively adsorbed on pyrite. This selective adsorption is important considering that silica is more abundant in the natural environment than pyrite. If Ti-catechol complex is applied to prevent pyrite oxidation in actual situation, it can be expected that the presence of silica would have no effect on the adsorption of Ti on pyrite.

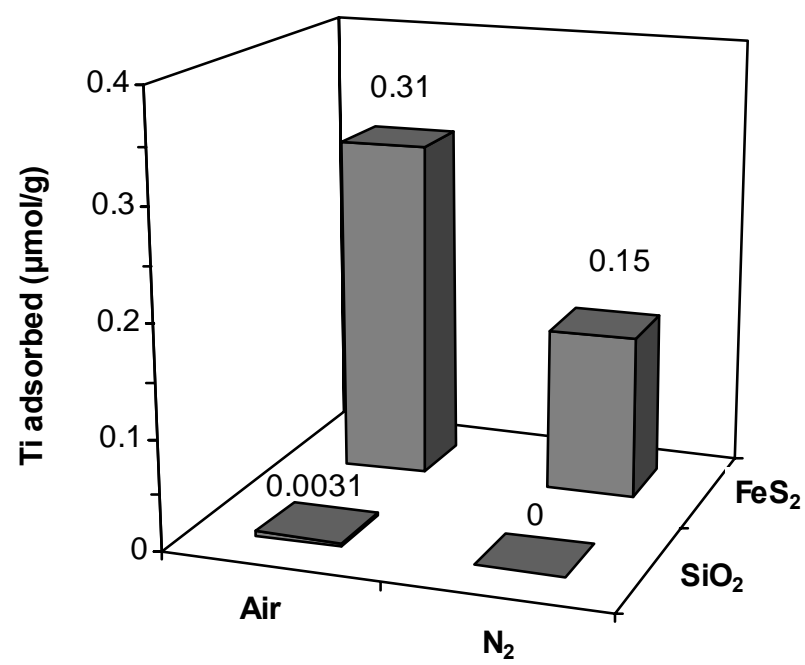

Fig. 5. Adsorption amount of Ti on pyrite and on silica with or without $\mathrm{O}_{2}$ at $25^{\circ} \mathrm{C}$ after 1 day. Initial Ti concentration and $\mathrm{pH}$ were $0.22 \mathrm{~mol} \mathrm{~m}^{-3}$ and 5.8, respectively.

The result in Fig. 5 also shows that the adsorption amount of Ti on pyrite was larger in air than in $\mathrm{N}_{2}$, indicating that $\mathrm{O}_{2}$ enhances Ti adsorption on pyrite. Since $\mathrm{O}_{2}$ is an oxidant, this result implies that an oxidation process plays an important role in Ti adsorption on pyrite from Ti-catechol complex solutions. 
Fig. 6 shows the cyclic voltammogram for pyrite electrode in $10 \mathrm{~mol} \mathrm{~m}^{-3} \mathrm{Na}_{2} \mathrm{SO}_{4}$ with and without $10 \mathrm{~mol} \mathrm{~m}^{-3}$ catechol at natural $\mathrm{pH}(\mathrm{pH} 5-6)$. At redox potential greater than 0.25 $\mathrm{V}$, a larger anodic current was observed in the presence of $10 \mathrm{~mol} \mathrm{~m}^{-3}$ catechol than without catechol. This indicates that catechol was oxidized on pyrite surface. The oxidation of catechol may be assumed to form quinone, $\mathrm{C}_{6} \mathrm{H}_{4} \mathrm{O}_{2}$, as follows:
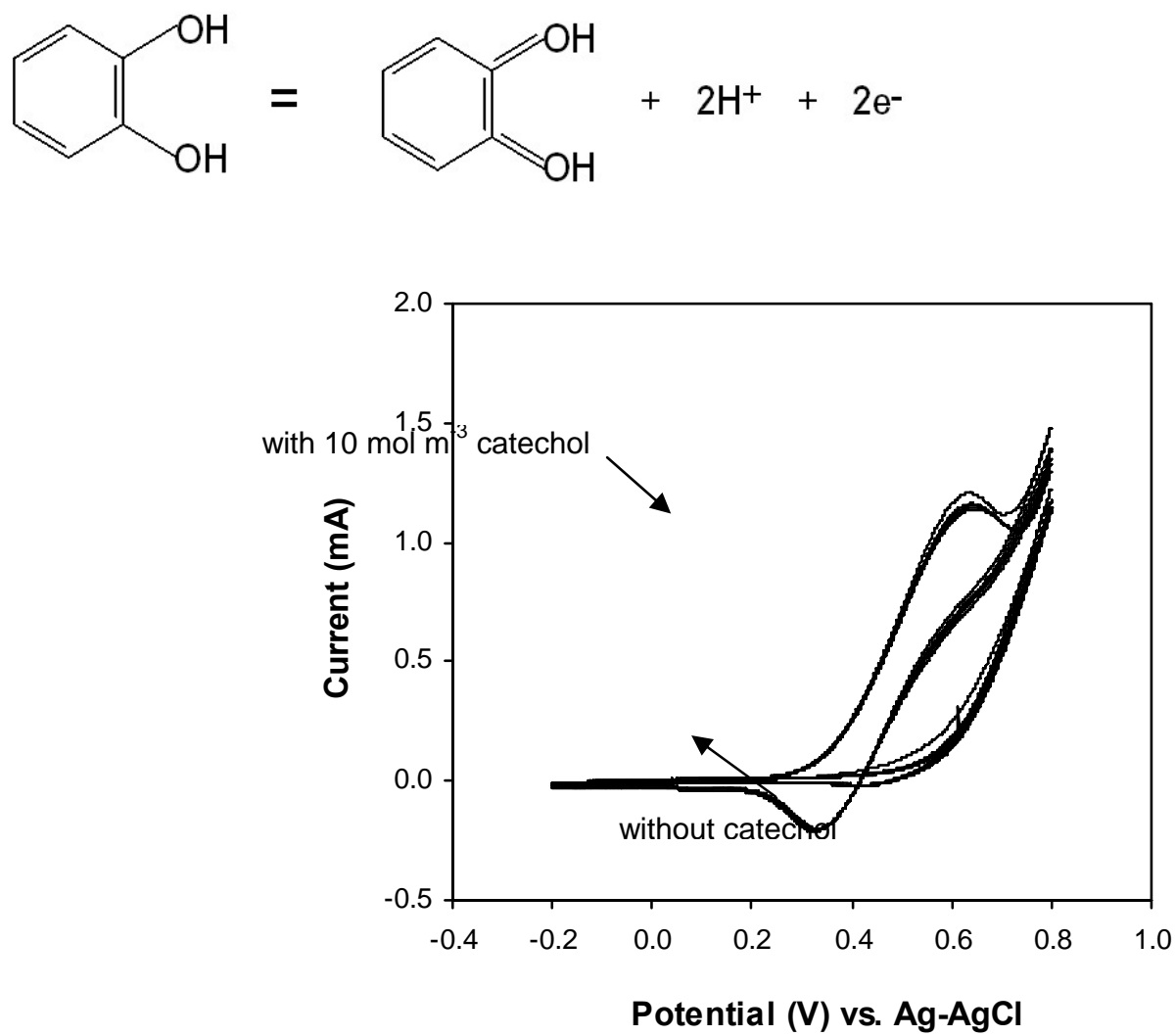

Fig. 6. Cyclic voltammogram for pyrite electrode in $10 \mathrm{~mol} \mathrm{~m}^{-3} \mathrm{Na}_{2} \mathrm{SO}_{4}$ with and without 10 $\mathrm{mol} \mathrm{m} \mathrm{m}^{-3}$ catechol at natural $\mathrm{pH}(\mathrm{pH} \mathrm{5-6)}$.

Based on the above results, the Ti adsorption on pyrite surface from Ti-catechol complex solution is assumed to be due to the following anode reactions:

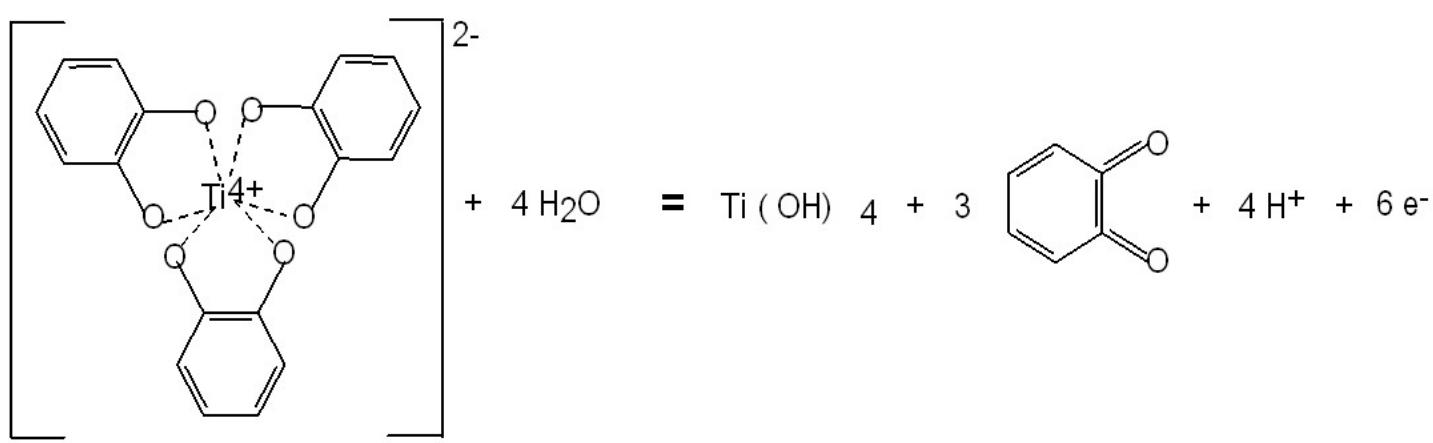




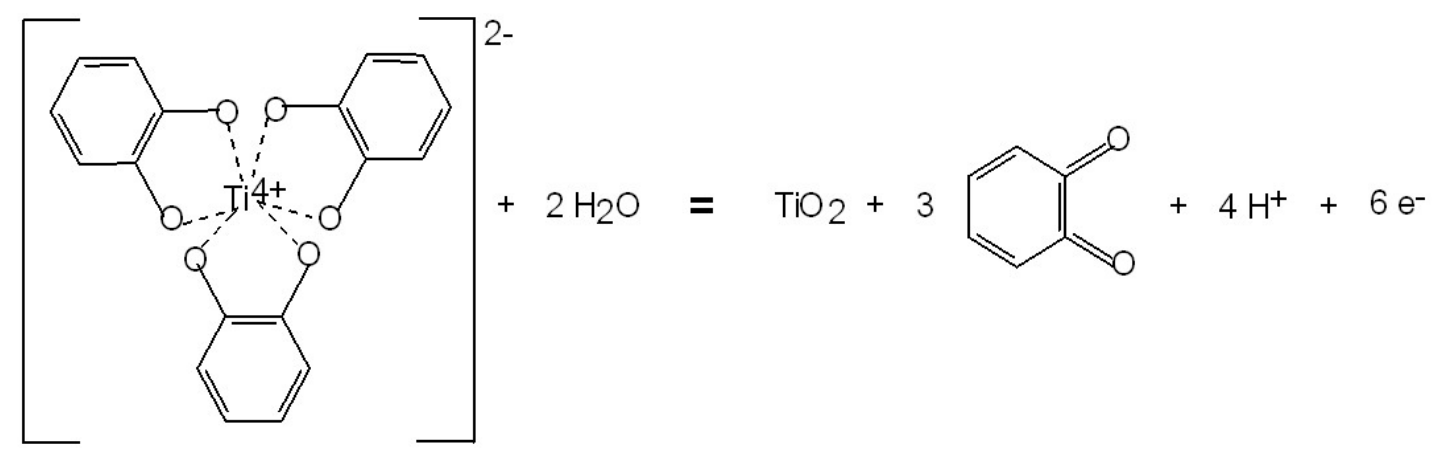

The released electrons in the above reaction may be consumed by oxygen on the cathode site of the pyrite surface as follows:

$\mathrm{O}_{2}+4 \mathrm{H}^{+}+4 e^{-}=2 \mathrm{H}_{2} \mathrm{O}$

Summing up the anode and cathode reactions gives the overall reactions for Ti adsorption as follows:
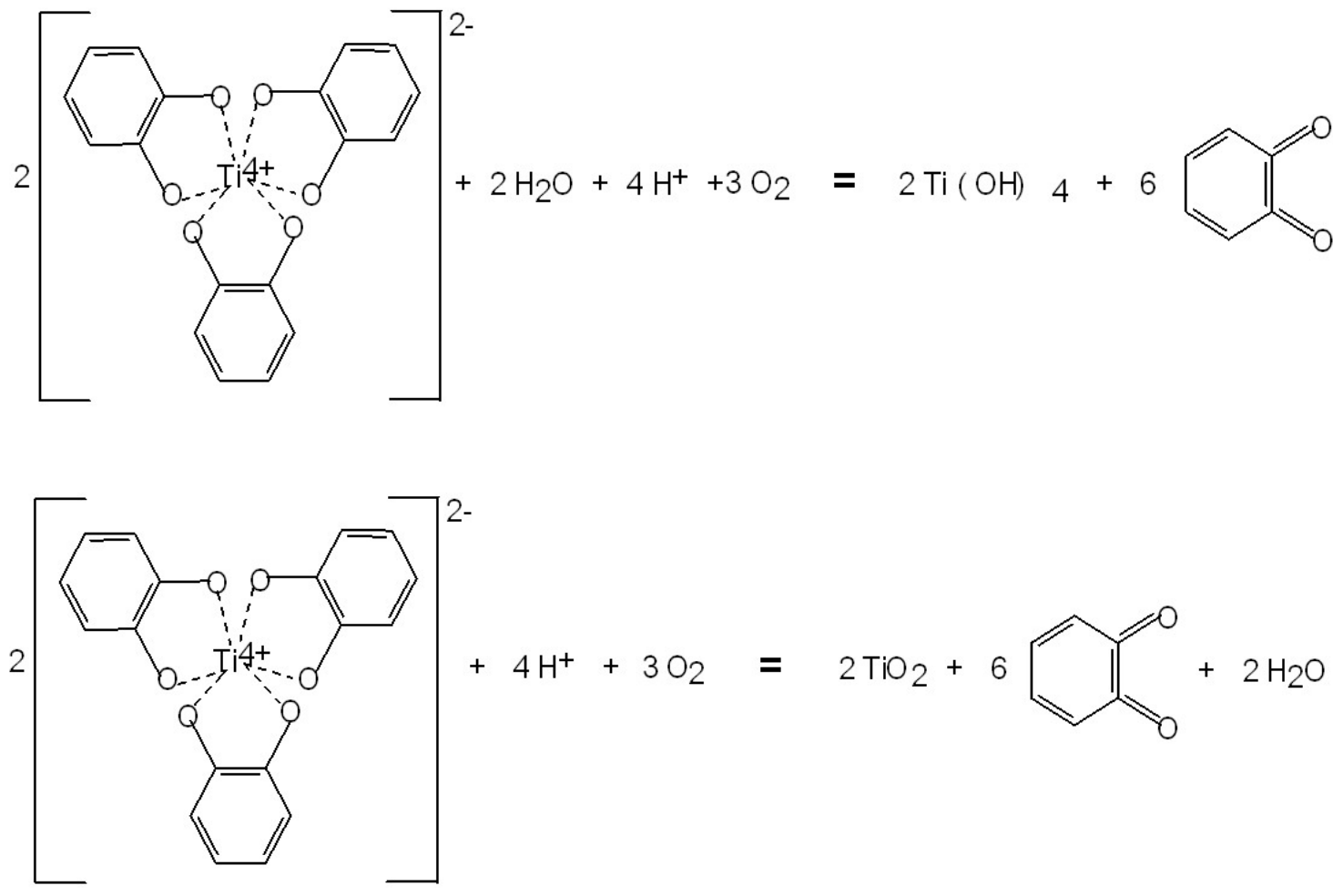

In the above equations, ortho-quinone is assumed to be a product of the reactions, but this assumption needs to be confirmed in future investigations. The oxidation mechanism may be very complex and adsorption of catechol or its oxidized product on the pyrite may occur. In this study, surface analysis like IR was not done for establishing the surface reactions between catechol and $\mathrm{Fe}$ and $\mathrm{S}$ in pyrite. Because of this, the detailed mechanism for the surface reactions cannot be discussed at the present but will be investigated in further studies.

\subsection{Effects of CME on pyrite oxidation}


The effects of CME using $\mathrm{TiO}_{2}$ and catechol on pyrite oxidation were investigated by shaking-flask leaching experiment of $72 \mathrm{~g}$ pyrite in $120 \mathrm{~cm}^{3}$ solution containing $100 \mathrm{~mol} \mathrm{~m}^{-3}$ catechol and $12 \mathrm{~g}$ anatase $\mathrm{TiO}_{2}$ inside a $500-\mathrm{cm}^{3}$ Erlenmeyer flask for 25 days in air. For comparison, leaching experiments of pyrite with sole addition of $\mathrm{TiO}_{2}$ or catechol and a control experiment without $\mathrm{TiO}_{2}$ and catechol were also conducted. The results are shown in Figs. 7-10.

As shown in Fig. 7, significant amounts of Fe and $\mathrm{S}$ were released from pyrite in the control (without catechol and $\mathrm{TiO}_{2}$ ). This would be due to pyrite oxidation by $\mathrm{O}_{2}$ according to

$$
\begin{aligned}
& \mathrm{FeS}_{2}+7 / 2 \mathrm{O}_{2}+\mathrm{H}_{2} \mathrm{O}=\mathrm{Fe}^{2+}+2 \mathrm{SO}_{4}{ }^{2-}+2 \mathrm{H}^{+} \\
& \mathrm{FeS}_{2}+2 \mathrm{H}^{+}+1 / 2 \mathrm{O}_{2}=\mathrm{Fe}^{2+}+2 \mathrm{~S}+\mathrm{H}_{2} \mathrm{O}
\end{aligned}
$$

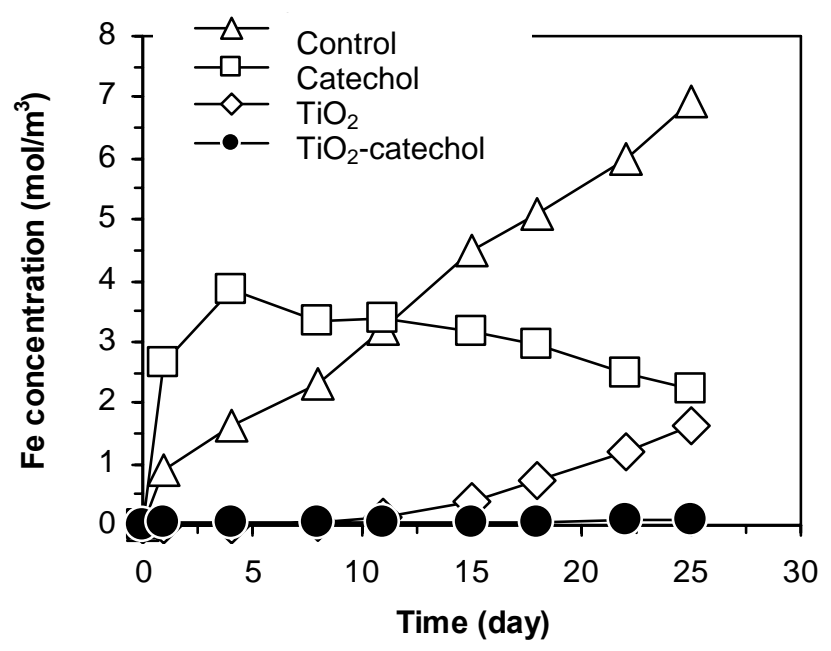

(a)

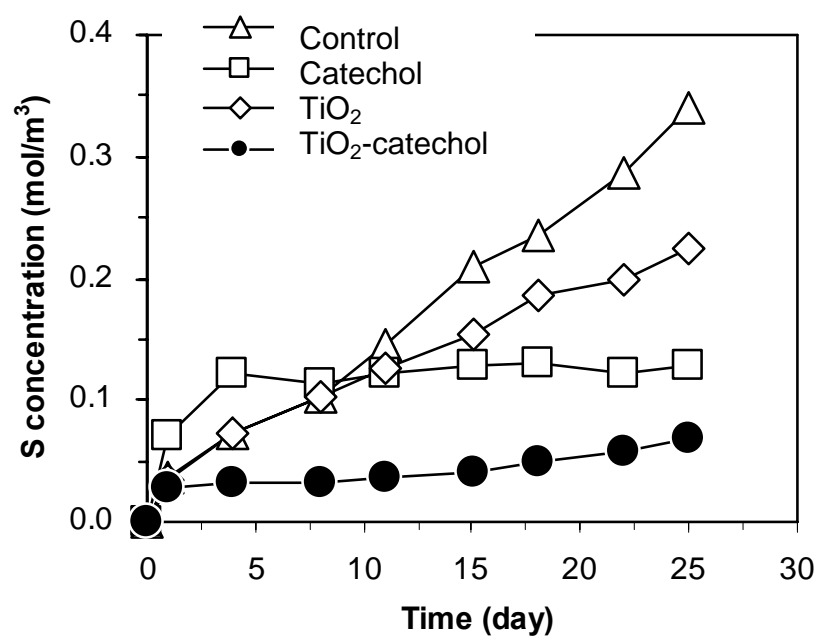

(b)

Fig. 7. Effects of anatase $\mathrm{TiO}_{2}$ and catechol on (a) $\mathrm{Fe}$ and (b) $\mathrm{S}$ released during pyrite oxidation. 
In comparison with the control, the amounts of $\mathrm{Fe}$ and $\mathrm{S}$ released were smaller with $\mathrm{TiO}_{2}$. The amount of Fe released at the early period of the leaching with $\mathrm{TiO}_{2}$ was almost negligible although substantial amount of $\mathrm{S}$ was released. The suppression in Fe release may be caused by the oxidation of $\mathrm{Fe}^{2+}$ to $\mathrm{Fe}^{3+}$ (Eq. 10) and subsequent precipitation of $\mathrm{Fe}^{3+}$ as a hydroxide (Eq. 11) due to the higher $\mathrm{pH}$ in the presence of $\mathrm{TiO}_{2}$ at the early period (Fig. 8).

$$
\begin{aligned}
& \mathrm{Fe}^{2+}+\mathrm{H}^{+}+1 / 4 \mathrm{O}_{2}=\mathrm{Fe}^{3+}+1 / 2 \mathrm{H}_{2} \mathrm{O} \\
& \mathrm{Fe}^{3+}+3 \mathrm{H}_{2} \mathrm{O}=\mathrm{Fe}(\mathrm{OH})_{3}+3 \mathrm{H}^{+}
\end{aligned}
$$

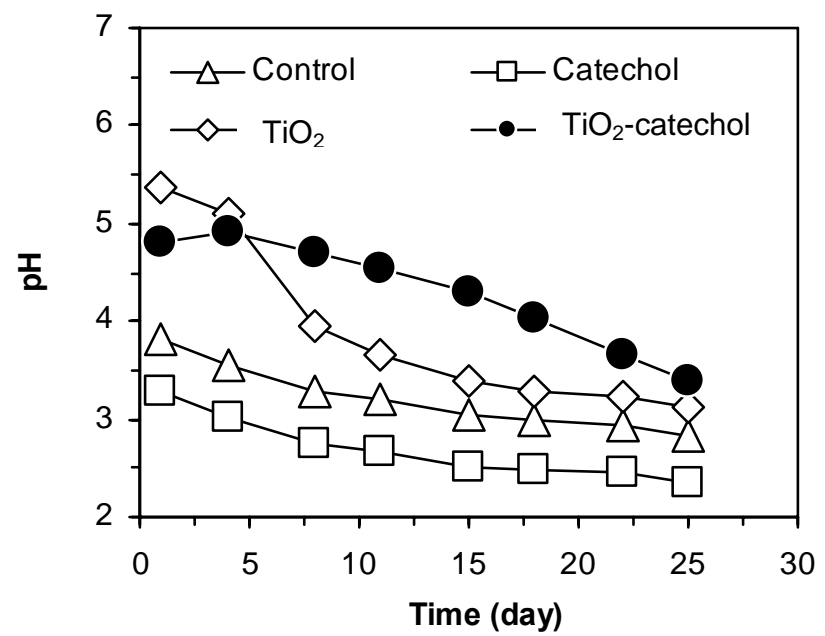

(a)

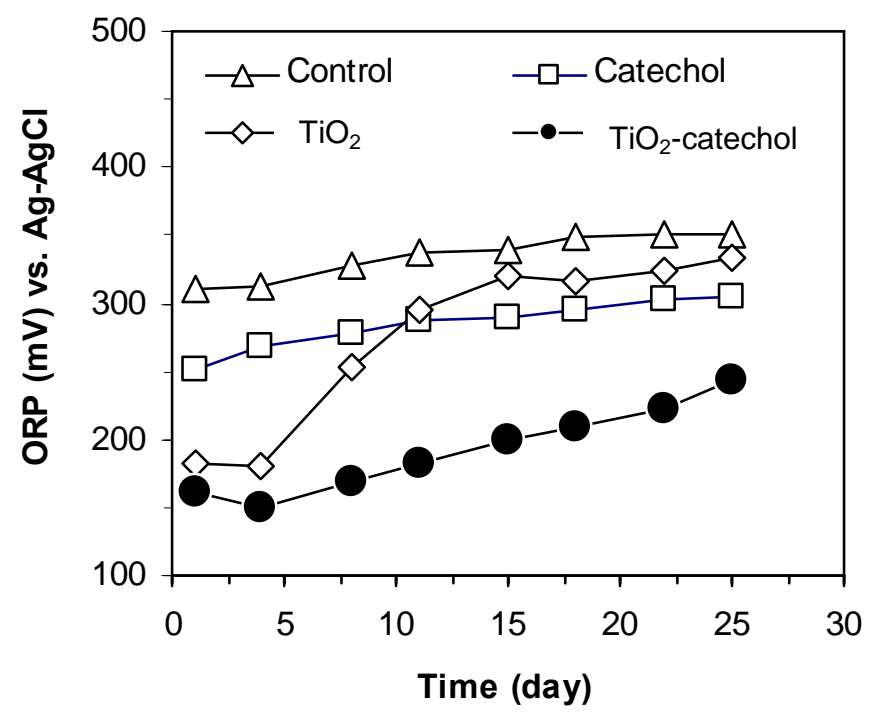

Fig. 8. Effects of anatase $\mathrm{TiO}_{2}$ and catechol on (a) $\mathrm{pH}$ and (b) ORP during pyrite oxidation.

In the presence of catechol (Fig. 7), higher amounts of $\mathrm{Fe}$ and $\mathrm{S}$ were released than the control at the early period of leaching, possibly due to the enhancement of pyrite oxidation by the formation of Fe-catechol complexes (Luther et al., 1992). After 4 days, Fe concentrations decreased with time, indicating that Fe released from pyrite is precipitated according to the reaction in Eq. 11. The $\mathrm{pH}$ of the solution decreased gradually from $\mathrm{pH} 3.29$ to $\mathrm{pH} 2.41$. The concentrations of $\mathrm{S}$ after 4 days almost remained constant, implying that 
$\mathrm{SO}_{4}{ }^{2-}$ formation according to the pyrite oxidation in Eq. 8 has stopped. A possible explanation for this is that iron precipitate covers the pyrite surface and suppresses the oxidation in Eqs. 8 and 9. The action of catechol as a reductant might also have caused the suppression of pyrite oxidation, because $\mathrm{O}_{2}$ and $\mathrm{Fe}^{3+}$, which are oxidants to pyrite, are consumed by catechol (Pracht et al., 2001).

The release of $\mathrm{Fe}$ and $\mathrm{S}$ was significantly suppressed when $\mathrm{TiO}_{2}$ and catechol coexisted (Fig. 7). Even with sole addition of $\mathrm{TiO}_{2}$ or catechol, suppression in Fe and $\mathrm{S}$ release was recognized but the suppression was much greater with coexistence of $\mathrm{TiO}_{2}$ and catechol. As shown in Fig. 8, $\mathrm{pH}$ of the $\mathrm{TiO}_{2}$-catechol system ( $\left.\mathrm{pH} 3.5-5\right)$ was observed to be the highest after the fifth day and its ORP the lowest, supporting that oxidation of pyrite is most effectively suppressed by CME using $\mathrm{TiO}_{2}$ and catechol. As shown in Fig. 9, when $\mathrm{TiO}_{2}$ and catechol coexisted, significant amounts of Ti were detected in the solution phase. For the first 5 days, Ti concentration increased with time, indicating that $\mathrm{Ti}$ is extracted from $\mathrm{TiO}_{2}$ in the presence of catechol. After 5 days, Ti concentration decreased with time, implying that the extracted $\mathrm{Ti}$ is adsorbed on the pyrite surface.

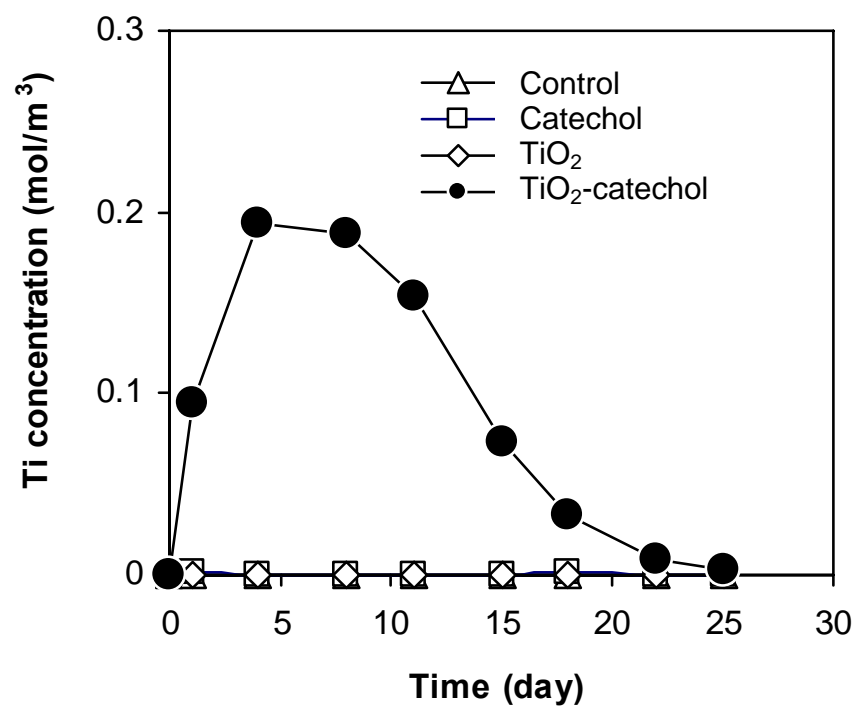

Fig. 9. Ti concentration profile with time in the leaching experiment of pyrite with anatase $\mathrm{TiO}_{2}$ and catechol.

Fig. 10 shows the element mapping by SEM-EDX analysis of the pyrite residue leached in the presence of $\mathrm{TiO}_{2}$ and catechol. The result shows that $\mathrm{Ti}$ and $\mathrm{O}$ are present on the pyrite surface, confirming the adsorption of $\mathrm{Ti}$ and also suggesting that $\mathrm{Ti}(\mathrm{OH})_{4}$ or $\mathrm{TiO}_{2}$ coating was formed on pyrite surface when $\mathrm{TiO}_{2}$ and catechol coexisted. Since Fe and $\mathrm{S}$ signals from pyrite were also detected through the $\mathrm{TiO}_{2}$ or $\mathrm{Ti}(\mathrm{OH})_{4}$ coating formed on pyrite surface, it may be inferred that the thickness of the coating is very thin (possibly less than 1 $\mu \mathrm{m})$. 

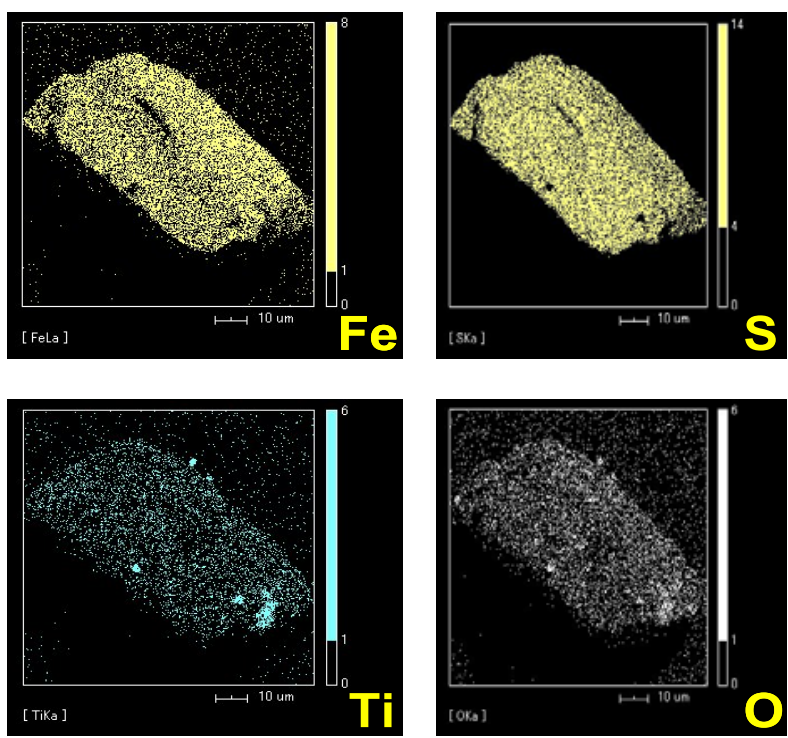

Fig. 10. Element mapping by SEM-EDX analysis of the pyrite residue leached in the presence of anatase $\mathrm{TiO}_{2}$ and catechol.

Based on the results that indicated the presence of Ti and $\mathrm{O}$ on pyrite surface (Figs. 9 and 10), it may be assumed that the $\mathrm{TiO}_{2}$ and catechol coexistence suppresses pyrite oxidation by the formation of a $\mathrm{Ti}(\mathrm{OH})_{4}$ or $\mathrm{TiO}_{2}$ coating on pyrite surface following the proposed redox mechanism in Section 3.2.

\subsection{Factors affecting the effect of CME on pyrite oxidation}

The effects of $\mathrm{pH}$, concentration of catechol, amount of anatase $\mathrm{TiO}_{2}$, and use of rutile $\mathrm{TiO}_{2}$ instead of anatase $\mathrm{TiO}_{2}$ on the pyrite oxidation with $\mathrm{TiO}_{2}$ and catechol were investigated by shaking-flask leaching experiments of $6 \mathrm{~g}$ pyrite in $10 \mathrm{~cm}^{3}$ of catechol solution and $\mathrm{TiO}_{2}$ inside a $50-\mathrm{cm}^{3}$ Erlenmeyer flask for 7 days in air.

Fig. 11 shows the effect of $\mathrm{pH}$ on $\mathrm{Fe}$ and $\mathrm{S}$ released during pyrite oxidation in the presence of $100 \mathrm{~mol} \mathrm{~m}^{-3}$ catechol and $1 \mathrm{~g}$ of anatase $\mathrm{TiO}_{2}$. The solution $\mathrm{pH}$ was varied by adding $\mathrm{H}_{2} \mathrm{SO}_{4}$ or $\mathrm{NaOH}$ to the catechol solution. The amounts of $\mathrm{Fe}$ and $\mathrm{S}$ released from pyrite were lower with anatase $\mathrm{TiO}_{2}$ and catechol than without them (control) at $\mathrm{pH}$ below 5, indicating that $\mathrm{CME}$ with $\mathrm{TiO}_{2}$ and catechol is effective in suppressing pyrite oxidation at the acidic region. However, at $\mathrm{pH}$ about 6 , the suppression of pyrite oxidation by the addition of $\mathrm{TiO}_{2}$ and catechol was not recognized. This may be explained from the overall reaction of $\mathrm{Ti}$ adsorption on pyrite (Eqs. 6 and 7): $\mathrm{Ti}$ adsorption, i.e. $\mathrm{TiO}_{2}$ or $\mathrm{Ti}(\mathrm{OH})_{4}$ protective coating, is suppressed when the concentration of $\mathrm{H}^{+}$is low, because $\mathrm{H}^{+}$is a reactant in Eqs. 6 and 7. 


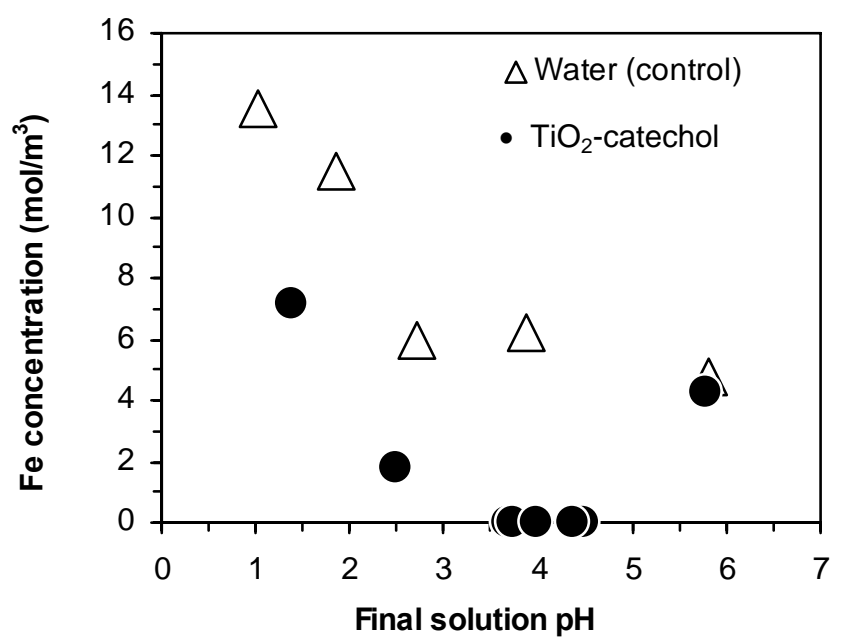

(a)

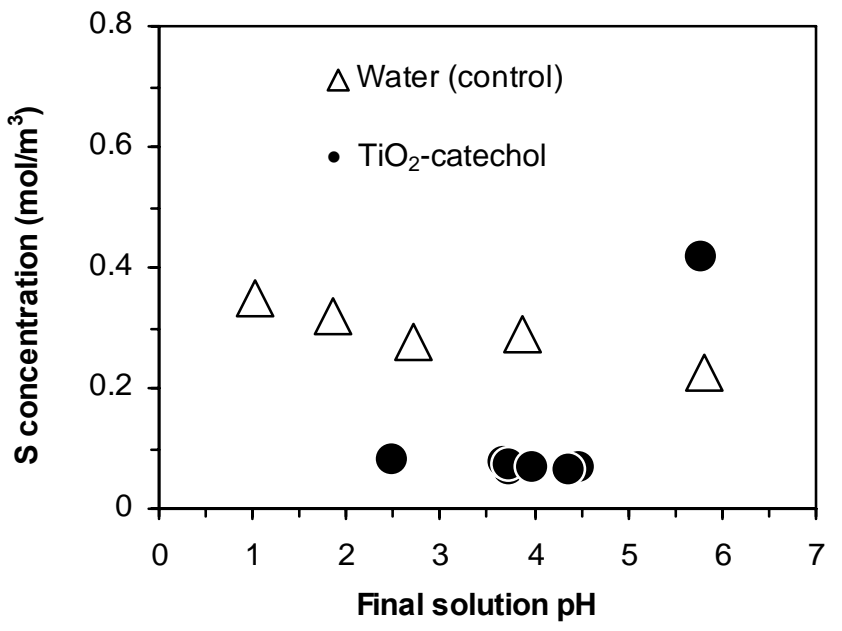

(b)

Fig. 11. Amounts of (a) Fe and (b) $\mathrm{S}$ released from pyrite leached with anatase $\mathrm{TiO}_{2}$ and catechol as a function of final solution $\mathrm{pH}$ after 7 days.

At natural $\mathrm{pH}(\mathrm{pH} 5-6)$, the effect of catechol concentration shows that decreasing the concentration of catechol from 100 to $10 \mathrm{~mol} \mathrm{~m}^{-3}$ still lowered the amount of Fe and $\mathrm{S}$ released (Fig. 12). This is a good result in terms of economic considerations in applying CME in actual situation. 


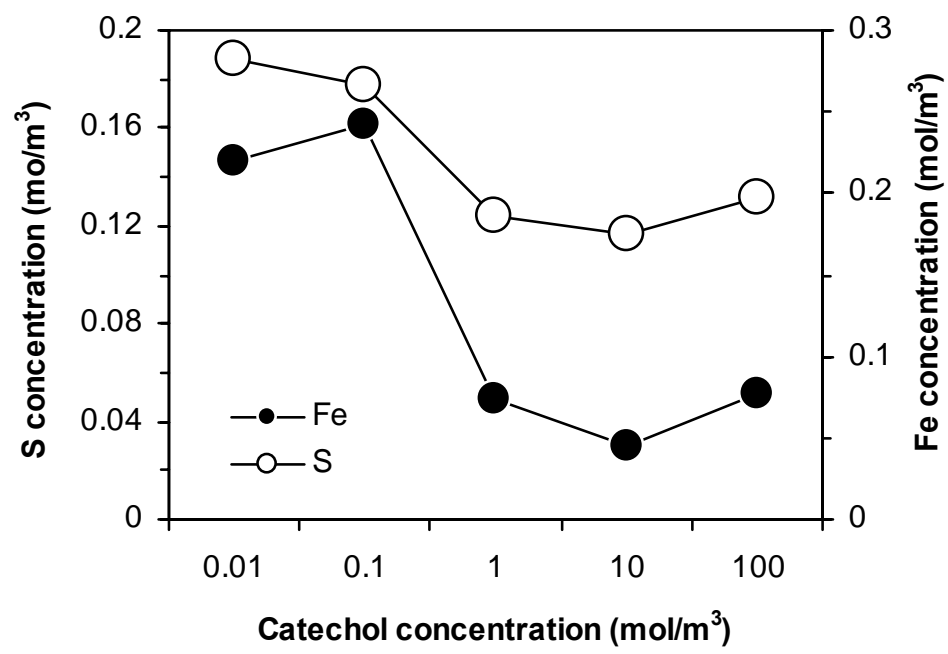

Fig. 12. Amounts of Fe and $\mathrm{S}$ released from pyrite leached with anatase $\mathrm{TiO}_{2}$ and catechol as a function of catechol concentration at natural $\mathrm{pH}(\mathrm{pH} 5-6)$ after 7 days.

Using $10 \mathrm{~mol} \mathrm{~m}^{-3}$ catechol, the amount of anatase $\mathrm{TiO}_{2}$ was then varied. However, decreasing the amount of $\mathrm{TiO}_{2}$ from $1 \mathrm{~g}$ to $0.01 \mathrm{~g}$ increased the amounts of $\mathrm{Fe}$ and $\mathrm{S}$ released (Fig. 13). Therefore, $10 \mathrm{~cm}^{3}$ of $10 \mathrm{~mol} \mathrm{~m}^{-3}$ catechol and $1 \mathrm{~g}$ of $\mathrm{TiO}_{2}$ are found to be optimum for suppressing pyrite oxidation.

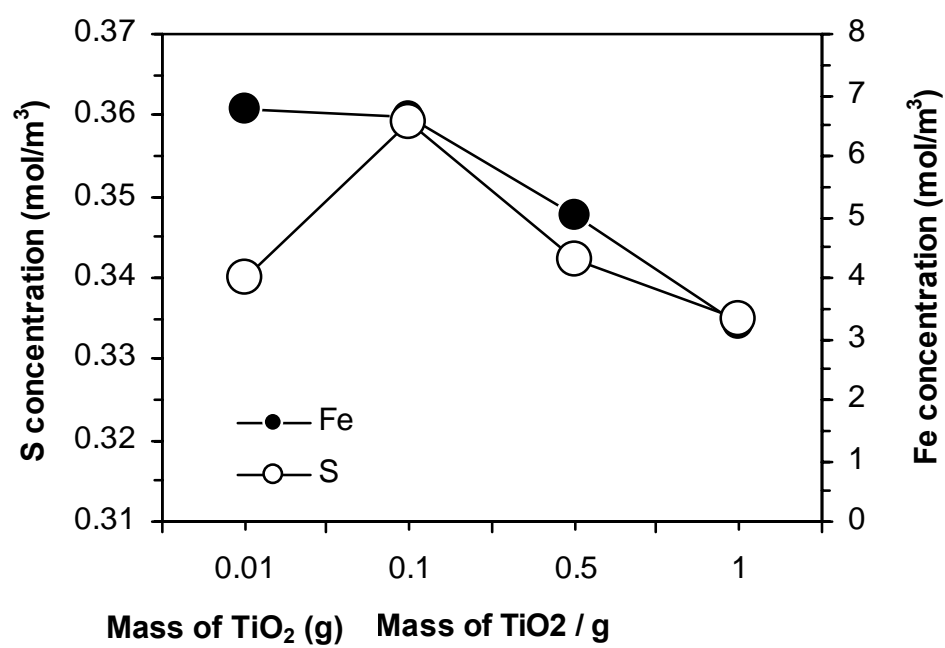

Fig. 13. Amounts of $\mathrm{Fe}$ and $\mathrm{S}$ released from pyrite leached with anatase $\mathrm{TiO}_{2}$ and $10 \mathrm{~mol} \mathrm{~m}^{-3}$ catechol as a function of mass of anatase $\mathrm{TiO}_{2}$ at natural $\mathrm{pH}(\mathrm{pH} 5-6)$ after 7 days.

The effect of CME using rutile $\mathrm{TiO}_{2}$ instead of anatase $\mathrm{TiO}_{2}$ in the pyrite leaching with $1 \mathrm{~g}$ of $\mathrm{TiO}_{2}$ and $100 \mathrm{~mol} \mathrm{~m}^{-3}$ catechol at natural $\mathrm{pH}(\mathrm{pH} \mathrm{5-6)}$ was investigated. Anatase was used in the adsorption and leaching experiments of pyrite but in the natural environment, rutile is the more common form of $\mathrm{TiO}_{2}$. Fig. 14 shows that pyrite oxidation in terms of $\mathrm{Fe}$ and $\mathrm{S}$ released was also suppressed with using rutile $\mathrm{TiO}_{2}$, although to a lesser extent than with using anatase $\mathrm{TiO}_{2}$. The significance of this result is that pyrite oxidation can be expected to be suppressed in actual application of CME (using catechol as organic carrier) for pyrite or sulfide minerals containing Ti minerals which could most probably exist as rutile $\mathrm{TiO}_{2}$. 


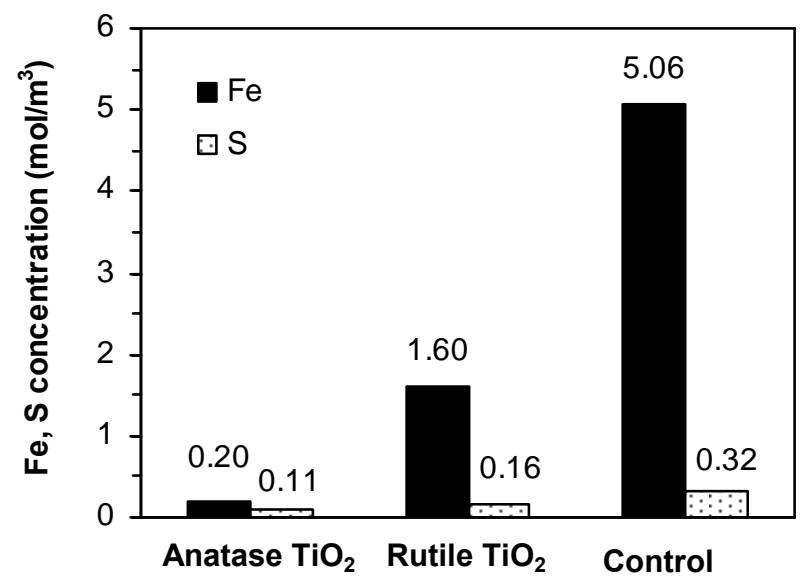

Fig. 14. Amounts of $\mathrm{Fe}$ and $\mathrm{S}$ released from pyrite leached with $1 \mathrm{~g}$ of anatase $\mathrm{TiO}_{2}$ or rutile $\mathrm{TiO}_{2}$ and $100 \mathrm{~mol} \mathrm{~m}^{-3}$ catechol at natural $\mathrm{pH}(\mathrm{pH} 5-6)$ after 7 days.

With respect to the use of catechol and its by-products, catechol is readily biodegradable and has no potential to bioaccumulate in the environment (Speciality Chemicals Magazine, 2002; Gericke and Ficher, 1979). Catechol is not classified as dangerous for the environment according to Annex 1 of CEE/67/548 directive by the Council of European Community (Speciality Chemicals Magazine, 2002). It can be degraded by air (Hathway and Seakins, 1957) and by ferric ions (Pracht et al., 2001). Microorganisms such as methanogenic bacteria (Healy and Young, 1978), yeast (Margesin et al., 2005), and fungi (Krastanov et al., 2006) can also degrade catechol and related compounds. However, the effect of these degradation products on the environment still needs to be confirmed.

Catechol and related phenolic compounds can also be found naturally in aquatic and humic materials (Christman and Chassemi, 1966; Christman et al., 1978; Schnitzer and Khan, 1972) and are produced from wood-decaying fungi (Goodell et al., 1997). However, in actual application of CME, higher amount of catechol than what is naturally present will be needed. Its environmental effect should be investigated in the future.

\section{Conclusions}

In this study, carrier-microencapsulation (CME) was proposed for preventing pyrite oxidation and was demonstrated using catechol and $\mathrm{TiO}_{2}$. Titanium ions were extracted from $\mathrm{TiO}_{2}$ by catechol and were adsorbed on pyrite, indicating that catechol can act as an organic carrier agent for Ti ions from $\mathrm{TiO}_{2}$ to pyrite. Pyrite oxidation was significantly suppressed by addition of both $\mathrm{TiO}_{2}$ and catechol in pyrite leaching experiments. Sole addition of $\mathrm{TiO}_{2}$ or catechol also suppressed pyrite oxidation but to a lesser extent than addition of both $\mathrm{TiO}_{2}$ and catechol. The formation of $\mathrm{Ti}(\mathrm{OH})_{4}$ or $\mathrm{TiO}_{2}$ coating on pyrite surface is assumed to be the cause of the suppression of pyrite oxidation by $\mathrm{TiO}_{2}$ and catechol.

\section{Acknowledgements}

We thank the Ministry of Education, Science and Technology (MEXT) of Japan for the support granted to this research. 


\section{References}

Chander S., Zhou R., 1992. Effect of organic additives on acid generation from pyrite waste. Proceedings of the Symposium on Emerging Process Technologies for a Cleaner Environment. Phoenix, Arizona, 24-27 February, pp. 131-139.

Christman R.F., Chassemi M.J., 1966. J. Amer. Water Works Assoc. 58, 723-741.

Christman R.F., et al., 1978. Water Chlorination: Environmental Impact and Health Effects, Vol. 2, Jolley R.L., et al. (Eds.). Ann Arbor Science Publishers, Michigan, pp. 15-28.

Elsetinow A.R., Borda M.J., Schonnen M.A.A., Strongin D.R., 2003. Suppression of pyrite oxidation in acidic aqueous environments using lipids having two hydrophobic tails. Advances in Environ. Res. 7, 967-974.

Evangelou V.P., 1995. Pyrite Oxidation and its Control. CRC Press, Florida.

Evangelou V.P., 2001. Pyrite microencapsulation technologies: principles and potential field application. Ecol. Eng. 17, 165-178.

Gericke P., Ficher W.K., 1979. A correlation study of biodegradability determinations with various chemicals in various tests. Ecotoxicol. Environ. Safety 3, 159-173.

Goodell B., Jellison J., Liu J., Daniel G., Paszczynski A., Fekete F., Krishnamurthy S., Jun L., Xu G., 1997. Low molecular weight chelators and phenolic compounds isolated from wood decay fungi and their role in the fungal biodegradation of wood. J. Biotech. 53, 133-162.

Hathway D.E., Seakins J.W., 1957. Enzymatic oxidation of catechin to a polymer structurally related to some phlobatannins. Biochem. J. 67, 239.

Healy J.B., Young L.Y., 1978. Catechol and phenol degradation by a methanogenic population of bacteria. App. Environ. Microb. 35, 216-218.

Kalin M., Smith M.P., Fayson A., 1998. The role of phosphate in applied biotechnology in mine waste management: reduction in AMD from pyritic waste rock, in: Rao S., Amaratunga L.M., Richards G.G., Kondos P.D. (Eds.), Water Processing and Recycling in Mineral and Metallurgical Industries III. Metallurgical Society of CIM, Montreal, Quebec, pp. 15-31.

Krastanov A., Stoilova I., Stanchev V., Daniel D., Gerginova M., Alexieva Z., 2006. Biodegradation of high amounts of phenol, catechol, 2,4-dichlorophenol and 2,6dimethoxyphenol by Aspergillus awamori cells. Enzy. Microb. Tech. 39, 1036-1041.

Luther III G.W., Kotska J.E., Church T.M., Sulzberger B., Stumm W., 1992. Seasonal iron cycling in the salt-marsh sedimentary environment: the importance of ligand complexes with $\mathrm{Fe}^{2+}$ and $\mathrm{Fe}^{3+}$ in the dissolution of $\mathrm{Fe}^{3+}$ minerals and pyrite, respectively. Marine Chem. 40, 81-103.

Margesin R., Bergauer P., Fonteyne P.A., Nolard N., Schinner F., 2005. Biodegradation of phenol and phenol-related compounds by psychrophilic and cold-tolerant alpine yeasts. Chemos. 59, 909-918.

Nagasawa S., Igarashi T., Asakura K., 2004. Neutralization of acid water resulting from pyrite by calcite-bearing rocks. Proceedings of the COE International Seminar on Water/Waste Metabolism and Groundwater Pollution. Sapporo, Japan, 19 May, pp. 30-31.

Pracht J., Boenigk J., Isenbeck-Schroter M., Keppler F., Scholer H.F., 2001. Abiotic $\mathrm{Fe}^{3+}$ induced mineralization of phenolic substances. Chemos. 44, 613-619.

Raymond K.N., Borgias B.A., Cooper S.R., Koh Y.B., 1984. Synthetic, structural, and physical studies of titanium complexes of catechol and 3,5-Di-tert-butylcatechol. Inorg. Chem. 23, 1009-1016.

Rodriguez R., Blesa M.A., Regazzoni A.E., 1996. Surface complexation at the $\mathrm{TiO}_{2}$ (anatase)/aqueous solution interface: chemisorption of catechol. J. Col. Inter. Sc. 177, 122-131. 
Sasaki K., Tsunekawa M., Ohtsuka T., Konno H., 1995. Confirmation of a sulfur-rich layer on pyrite after oxidative dissolution by $\mathrm{Fe}(\mathrm{III})$ ions around $\mathrm{pH}$ 2. Geochim. Cosmochim. Acta 59, 3155-3158.

Schnitzer M., Khan S.U., 1972. Humic Substances in the Environment. Marcel Dekker, New York.

Speciality Chemicals Magazine, 2002. Catechol: a chelating material for many applications. February, pp.16-18.

Taylor S.R., 1964. Abundance of chemical elements in the continental crust: a new table. Geochim. Cosmochim. Acta 28, 1273-1285. 